\title{
DETERMINAN STATUS KEMISKINAN ANAK PADA RUMAH TANGGA KRT PEREMPUAN DI PROVINSI BENGKULU 2018
}

\author{
(Determinants of Child Poverty Status in Female Headed Household in Bengkulu Province \\ 2018)
}

\author{
Karina Nur Fadila ${ }^{1}$, Agung Priyo Utomo ${ }^{2}$ \\ Politeknik Statistika STIS ${ }^{1}$ \\ Politeknik Statistika STIS 2 \\ Jalan Otto Iskandardinata No.64C 14 , RT.1/RW.4, Bidara Cina, Kecamatan Jatinegara, Kota Jakarta Timur, \\ Daerah Khusus Ibukota Jakarta 13330 \\ E-mail: 111709775@stis.ac.id
}

\begin{abstract}
ABSTRAK
Kemiskinan anak merupakan permasalahan serius. Salah satu faktor yang mempengaruhinya adalah jenis kelamin KRT. Anak pada rumah tangga KRT perempuan cenderung lebih berisiko mengalami kemiskinan dibanding anak pada rumah tangga KRT laki-laki. Hal tersebut disebabkan oleh adanya anggapan sosial bahwa perempuan merupakan masyarakat kelas dua. Provinsi Bengkulu merupakan provinsi di wilayah barat Indonesia dengan tingkat kemiskinan anak tertinggi pada tahun 2016 sehingga menjadi fokus dalam penelitian ini dengan tujuan untuk mengetahui gambaran umum, menganalisis faktor-faktor yang mempengaruhi, serta menganalisis kecenderungan variabel bebas terhadap status kemiskinan anak pada rumah tangga KRT perempuan di Provinsi Bengkulu tahun 2018. Data yang digunakan adalah data hasil praktik kerja lapangan mahasiswa Politeknik Statistika STIS tahun 2018. Dengan menggunakan metode analisis regresi logistik biner, diketahui bahwa pendidikan KRT, status pekerjaan KRT, jumlah ART, dan status perkawinan KRT berpengaruh signifikan terhadap kemiskinan anak KRT perempuan di Provinsi Bengkulu tahun 2018. Kecenderungan lebih besar terjadi pada anak dengan karakteristik pendidikan tertinggi KRT adalah di bawah SMA, KRT bekerja di sektor pertanian, memiliki jumlah ART besar, dan KRT berstatus kawin.
\end{abstract}

Kata kunci: Kemiskinan Anak, KRT Perempuan, Regresi Logistik Biner

\section{ABSTRACT}

Child poverty is a serious problem. One of the factors that affect it is the sex of the headed-household. Children with female-headed households tend to be more at risk of poverty than children with male-headed households. This is caused by the social assumption that women are a second class society. Bengkulu Province was a province in the western region of Indonesia with the highest child poverty rate in 2016 so that it becomes the focus of this study, whereas this study aims to determine the general picture, analyze the factors that affect, and analyze the tendency of independent variables on the poverty status of children with female headed-household in Bengkulu Province in 2018. The data used in this study is the results from the practical work of Politeknik Statistika STIS students in 2018. Using the binary logistic regression analysis method, it's known that the education of household heads, employment status of household heads, number of household members, and marital status of household heads have significant effect on child poverty with female-headed household in Bengkulu Province in 2018. The tendency is greater for children with the highest education of household heads are under senior high school, household heads work in the agricultural sector, have a large number of household members, and the marital status is marriage.

Keywords: Child Poverty, Female-headed Household, Binary Logistic Regression

\section{PENDAHULUAN}

Kemiskinan merupakan suatu permasalahan pokok yang terus dihadapi oleh seluruh negara di dunia. Tidak hanya berdampak pada bidang perekonomian, kemiskinan juga berdampak pada bidang-bidang kehidupan lainnya. Kemiskinan menyebabkan sulit terpenuhinya kebutuhan akses pada bidang-bidang tersebut. Sehingga pada akhirnya dapat mempengaruhi kualitas sumber daya manusia dan kualitas negara itu sendiri.

Banyak upaya pemberantasan kemiskinan telah dilakukan. Salah satunya adalah tertuangnya pengentasan kemiskinan sebagai salah satu tujuan SDGs (Sustainable Development Goals), dan 
telah disahkan oleh United Nation sebagai target pembangunan yang harus dicapai pada tahun 2030. Sebagai salah satu anggota United Nation, Indonesia juga telah turut serta melaksanakan program pengentasan kemiskinan. Dalam RPJMN 2015-2019, salah satu misi yang dilakukan oleh Indonesia adalah mewujudkan kualitas hidup manusia Indonesia yang tinggi, maju, dan sejahtera.

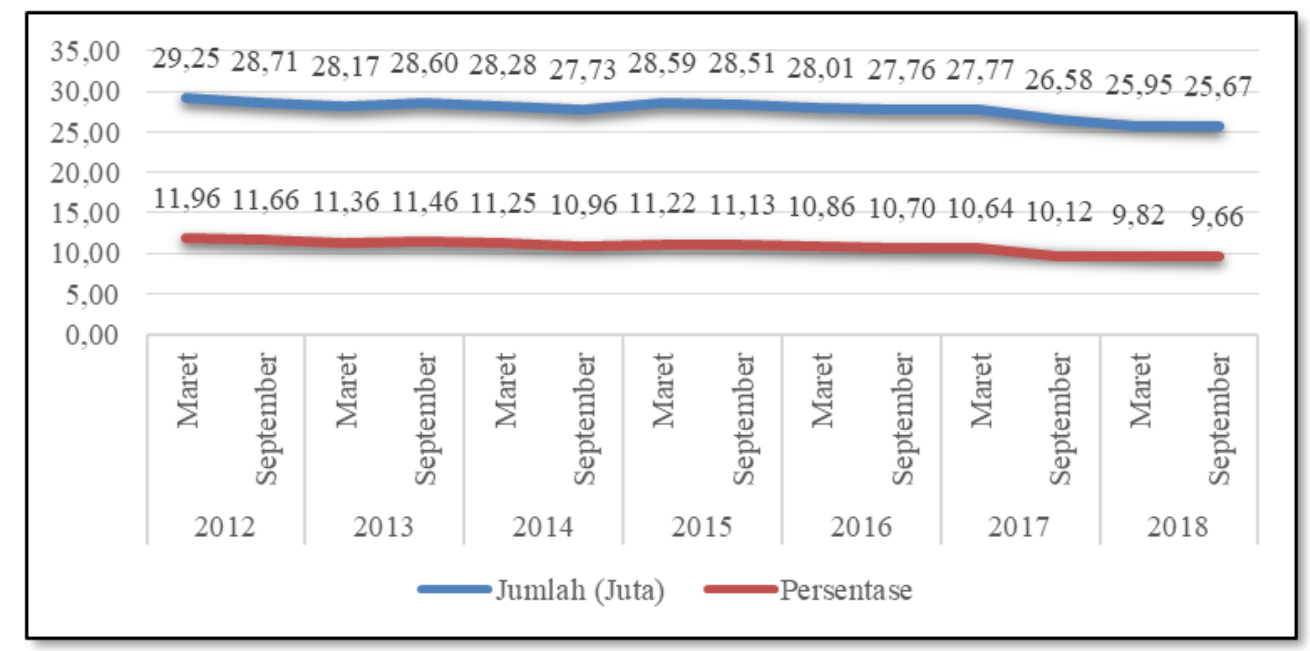

Sumber: $\quad$ Profil Kemiskinan di Indonesia September 2018

Gambar 1. Jumlah (juta) dan persentase penduduk miskin di Indonesia, Maret 2012September 2018.

Upaya pengentasan kemiskinan di Indonesia telah memberikan hasil yang cukup baik. Hal tersebut dibuktikan dengan angka penduduk miskin yang memiliki tren menurun setiap tahunnya (Gambar 1). Data yang diperoleh dari BPS menunjukkan bahwa pada Maret 2018 jumlah penduduk miskin adalah sebanyak 25,95 juta jiwa atau sebesar 9,82 persen, dan menurun menjadi 25,67 juta jiwa atau 9,66 persen pada bulan September tahun yang sama. Namun pengentasan kemiskinan masih perlu terus dilakukan. Terutama kemiskinan yang dialami oleh anak-anak sebagai generasi penerus bangsa.

Menurut UU Republik Indonesia nomor 35 tahun 2014 tentang perubahan atas UU nomor 23 tahun 2002 perlindungan anak, dikatakan bahwa anak adalah seseorang yang belum berusia 18 tahun, termasuk anak yang masih dalam kandungan. Sedangkan anak yang tergolong miskin adalah anak yang tinggal pada rumah tangga miskin (BPS, 2017).

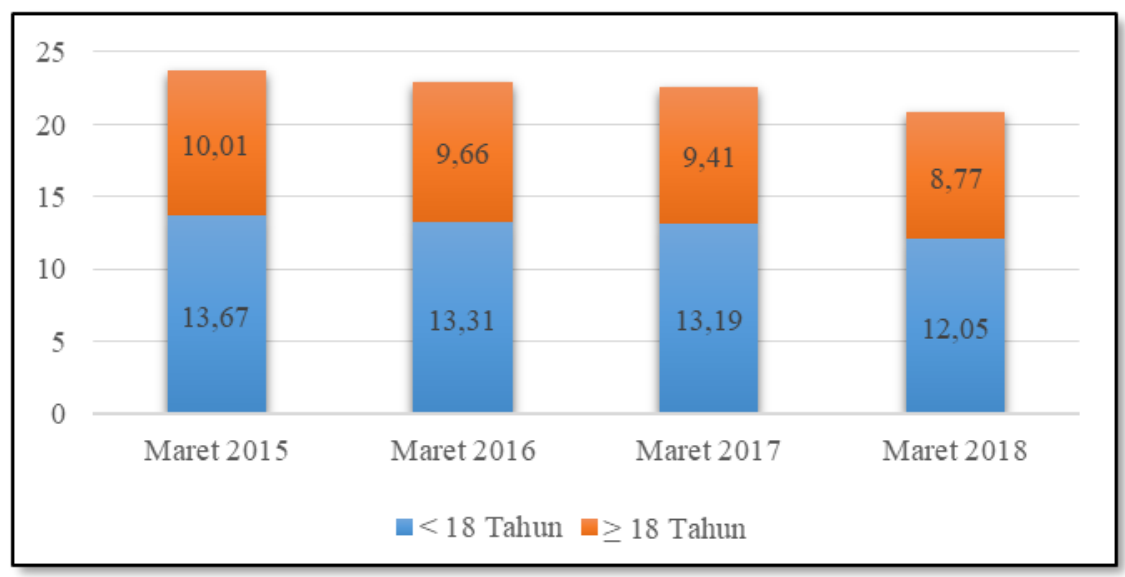

Sumber: bps.go.id

Gambar 2. Persentase penduduk yang hidup di bawah garis kemiskinan nasional menurut kelompok umur (persen), Maret 2015-Maret 2018.

Kemiskinan dapat terjadi pada berbagai kelompok masyarakat. Ambariyanto (2013) berpendapat bahwa dampak kemiskinan sangat terasa terutama bagi kelompok masyarakat rentan, seperti anak-anak dan perempuan. Anak ( $<18$ tahun) yang memiliki potensi besar sebagai penerus cita-cita bangsa, pada Maret 2015 hingga Maret 2018 memiliki persentase kemiskinan 
lebih banyak dibandingkan kelompok umur lainnya. Kemiskinan pada anak dapat menghambat pertumbuhan dan perkembangan sesuai potensi yang dimiliki (Astuti dkk, 2018). Akibatnya anak tidak dapat memiliki kualitas yang baik juga mumpuni. Hal tersebut selaras dengan pernyataan BPS dalam Analisis Kemiskinan Anak dan Deprivasi Hak-hak Dasar Anak di Indonesia (2017) bahwa anak yang tinggal pada keluarga miskin akan berdampak pada kesehatan dan gizinya, pencapaian pendidikan, dan kesejahteraan psikologis.

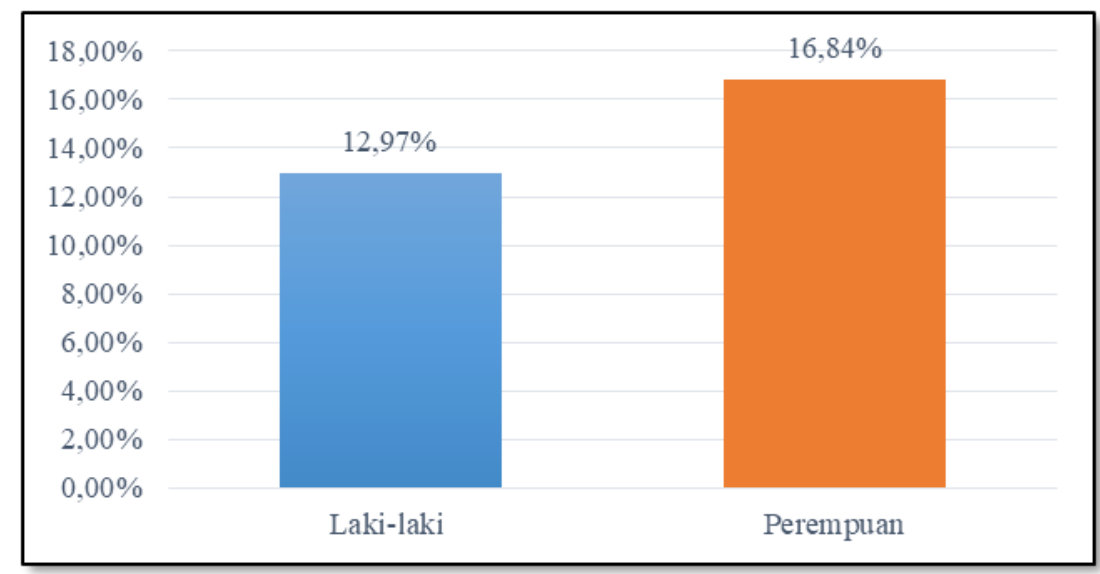

Sumber: $\quad$ Publikasi Analisis Kemiskinan Anak dan Deprivasi Hakhak Dasar Anak di Indonesia

Gambar 3. Persentase anak miskin menurut jenis kelamin KRT di Indonesia, 2016

Salah satu karakteristik yang memiliki pengaruh terhadap kemiskinan anak adalah jenis kelamin kepala rumah tangga. Berdasarkan gambar di atas, pada tahun 2016 di Indonesia, anak dengan kepala rumah tangga perempuan memiliki persentase miskin lebih tinggi daripada anak dengan kepala rumah tangga laki-laki. Pada rumah tangga dengan kepala rumah tangga perempuan pada tahun 2016 di Indonesia, persentase anak miskin adalah sebesar 16,84 persen, sedangkan pada rumah tangga dengan kepala rumah tangga laki-laki adalah sebesar 12,97 persen.

Tingginya angka kemiskinan anak pada rumah tangga KRT perempuan dapat disebabkan oleh anggapan sosial bahwa perempuan dianggap sebagai masyarakat kelas dua (Probosiwi, 2015). Sehingga dalam hubungannya dengan kemiskinan, kemungkinan perempuan hidup dalam kemiskinan akan lebih tinggi jika dibandingkan dengan laki-laki (Ahmad ddk, 2015).

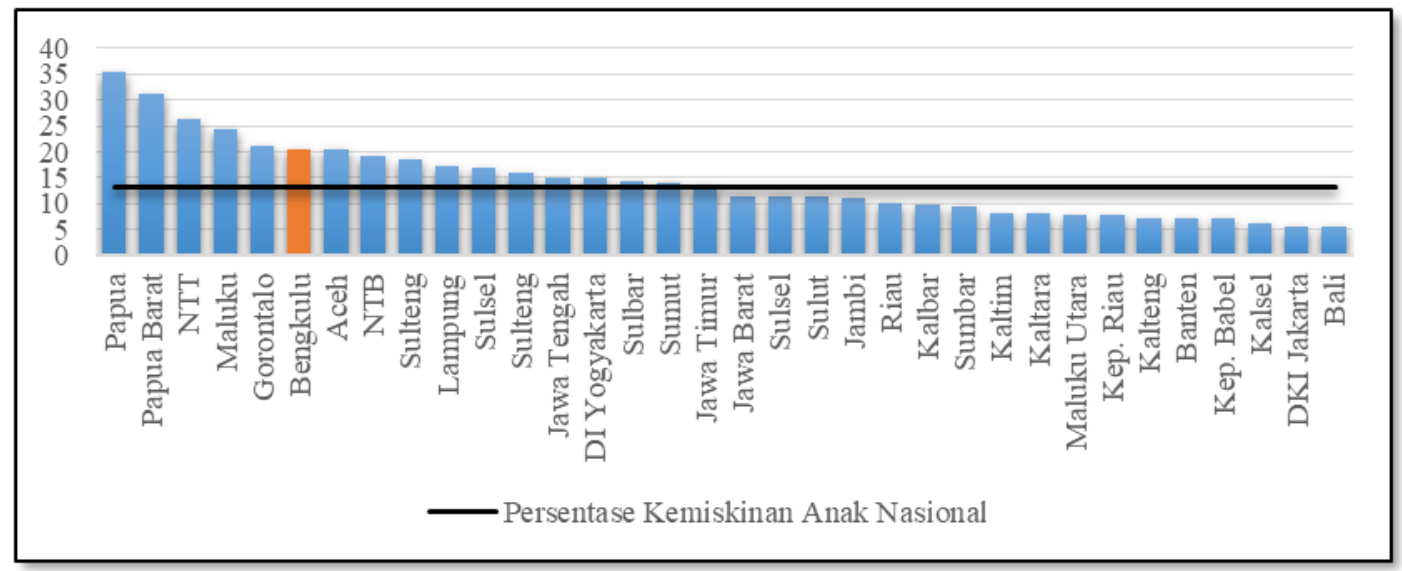

Sumber: $\quad$ Publikasi Analisis Kemiskinan Anak dan Deprivasi Hak-hak Dasar Anak di Indonesia

Gambar 4. Persentase anak miskin menurut provinsi di Indonesia, 2016

Persentase angka kemiskinan anak di Indonesia terus mengalami penurunan secara perlahan sejak Maret 2015 hingga Maret 2018 (Gambar 2). Namun jika dilihat menurut provinsi (Gambar 4), pada tahun 2016 masih terdapat beberapa wilayah yang memiliki persentase anak miskin di atas 
persentase nasional. Provinsi Bengkulu merupakan provinsi bagian barat Indonesia yang memiliki persentase kemiskinan anak tertinggi pada tahun 2016.

Menurut Putri, dkk (2019) kemiskinan dan gender secara umum memiliki keterkaitan dan rumah tangga KRT perempuan dianggap lebih miskin daripada rumah tangga KRT laki-laki dengan variabel yang mempengaruhinya adalah pendidikan KRT, status pekerjaan KRT, dan jumlah tanggungan dalam rumah tangga. Sari (2018) dalam penelitiannya menemukan bahwa status perkawinan KRT, status bekerja KRT, dan jumlah anak signifikan mempengaruhi kemiskinan. Berdasarkan penelitian Bachtiar, dkk (2016) diketahui bahwa pendidikan KRT, status pekerjaan KRT, klasifikasi tempat tinggal mempengaruhi kemiskinan anak balita di Provinsi Sumatera Barat. Sedangkan Satrio (2018) mengemukakan bahwa terdapat hubungan signifikan antara usia KRT, pendidikan KRT, dan sektor pekerjaan KRT terhadap status kemiskinan.

\section{METODE}

\section{CAKUPAN PENELITIAN}

Unit analisis yang digunakan dalam penelitian ini adalah anak berusia 0-17 tahun yang tinggal pada rumah tangga KRT perempuan di Provinsi Bengkulu tahun 2018. Seluruh anak pada rumah tangga KRT perempuan yang tergolong miskin diklasifikasikan sebagai anak yang mengalami kemiskinan. Sumber data merupakan data sekunder yang diperoleh dari hasil penelitian praktik kerja lapangan Politeknik Statistika STIS tahun 2018 di Provinsi Bengkulu. Penelitian ini hanya menggunakan data anak pada rumah tangga KRT perempuan di Provinsi Bengkulu tahun 2018. Variabel tak bebas yang digunakan adalah kemiskinan anak yang dibagi menjadi dua kategori yaitu anak yang mengalami kemiskinan dan anak yang tidak mengalami kemiskinan, sedangkan variabel bebas yang digunakan meliputi pendidikan tertinggi KRT, status pekerjaan KRT, klasifikasi tempat tinggal, jumlah ART, usia KRT, dan status perkawinan KRT.

\section{METODE ANALISIS}

Metode analisis yang digunakan dalam penelitian ini adalah analisis deskriptif dan analisis inferensia. Analisis deskriptif digunakan untuk memberikan gambaran umum mengenai variabel yang digunakan berupa tabel dan gambar. Sedangkan analisis inferensia digunakan untuk mengetahui variabel-variabel bebas yang mempengaruhi variabel tak bebas. Metode analisis inferensia yang digunakan dalam penelitian ini adalah regresi logistik biner, karena variabel tak bebas yang digunakan dikategorikan menjadi dua yaitu miskin (kode $=1$ ) dan tidak miskin (kode $=0$ ). Adapun tahapan pengujian yang dilakukan adalah:

1. Pengujian parameter secara simultan menggunakan uji likelihood ratio

$$
\mathrm{H}_{0}: \beta_{1}=\cdots=\beta_{j}=0
$$

$\mathrm{H}_{1}$ : Minimal ada satu $\beta_{j} \neq 0$ dimana $\mathrm{j}=1,2, \ldots, \mathrm{p}$ adalah banyaknya variabel bebas

Statistik uji yang digunakan adalah :

$$
G=-2 \ln \left(\frac{L_{0}}{L_{1}}\right)=-2\left[\ln \left(L_{0}\right)-\ln \left(L_{1}\right)\right] \sim \chi^{2}{ }_{(p)}
$$

dimana:

$$
\begin{aligned}
& L_{0}=\text { likelihood tanpa variabel bebas } \\
& L_{1}=\text { likelihood dengan variabel bebas }
\end{aligned}
$$

Sehingga pengambilan keputusan didasarkan pada:

1. Nilai $\mathrm{G}>\chi_{(\alpha ; p)}^{2}$ atau $\mathrm{p}$-value $<$ a maka tolak $\mathrm{H}_{0}$

2. Nilai $\mathrm{G} \leq \chi_{(\alpha ; p)}^{2}$ atau $\mathrm{p}$-value $\geq$ a maka gagal tolak $\mathrm{H}_{0}$

Jika pada pengujian simultan diperoleh keputusan tolak $\mathrm{H}_{0}$, diartikan bahwa dengan tingkat signifikansi sebesar $a$, minimal terdapat satu variabel bebas yang berpengaruh terhadap variabel tak bebas.

\section{Pengujian parameter secara parsial menggunakan uji wald}




$$
\begin{aligned}
& \mathrm{H}_{0}: \beta_{j}=0 \\
& \mathrm{H}_{1}: \beta_{j} \neq 0 \text { dimana } \mathrm{j}=1,2, \ldots, \mathrm{p} \text { adalah banyaknya variabel bebas }
\end{aligned}
$$

Statistik uji Wald yang digunakan adalah :

$$
W_{j}=\left[\frac{\widehat{\beta}_{j}}{\operatorname{se}\left(\widehat{\beta}_{j}\right)}\right]^{2} \sim \chi^{2}{ }_{(1)}
$$

dimana:

$$
\begin{aligned}
& \hat{\beta}_{j} \quad=\text { estimasi parameter } \beta_{j} \\
& \operatorname{se}\left(\hat{\beta}_{j}\right)=\text { estimasi standard error dari } \hat{\beta}_{j}
\end{aligned}
$$

Sehingga pengambilan keputusan didasarkan pada :

1. $\mathrm{W}>\chi_{(\alpha, 1)}^{2}$ atau $\mathrm{p}$-value $<$ a maka tolak $\mathrm{H}_{0}$

2. $\mathrm{W} \leq \chi_{(\alpha, 1)}^{2}$ atau atau $\mathrm{p}$-value $\geq$ a maka gagal tolak $\mathrm{H}_{0}$

Jika diperoleh pengujian tolak $\mathrm{H}_{0}$, diartikan bahwa dengan tingkat signifikansi sebesar $\mathrm{a}$, terdapat pengaruh signifikan secara parsial antara variabel bebas ke-j terhadap variabel tak bebas.

3. Pengujian kesesuaian model (Goodness of Fit) menggunakan Hosmer dan lemeshow test

$\mathrm{H}_{0}$ : Model fit

$\mathrm{H}_{1}$ : Model tidak fit

Statistik uji yang digunakan adalah :

$\hat{C}=\sum_{k=1}^{g} \frac{\left(o_{k}-n_{k} \pi_{k}\right)^{2}}{n_{k} \pi_{k}\left(1-\pi_{k}\right)} \sim \chi_{(g-2)}^{2}$

dimana:

$\hat{\mathrm{C}} \quad=$ Statistik uji Hosmer-Lemeshow

$O_{1 k}=$ jumlah nilai variabel terikat pada kelompok ke-k

$n_{k} \quad=$ jumlah subjek pada kelompok ke-k

$\pi_{k} \quad=$ rata-rata peluang estimasi

$\mathrm{g}=$ jumlah kelompok

Sehingga pengambilan keputusan didasarkan pada :

1. $\hat{\mathrm{C}}>\chi_{(\alpha, g-2)}^{2}$ atau p-value $<$ a maka tolak $\mathrm{H}_{0}$

2. $\hat{\mathrm{C}} \leq \chi_{(\alpha, g-2)}^{2}$ atau $\mathrm{p}$-value $\geq$ a maka gagal tolak $\mathrm{H}_{0}$

Pada uji kesesuaian model, hasil yang diharapkan adalah gagal tolak $\mathrm{H}_{0}$ agar dapat diambil kesimpulan bahwa model yang terbentuk sesuai (tidak terdapat perbedaan hasil antara observasi dan hasil prediksi dari model).

4. Odds ratio

Odds dapat diinterpretasikan sebagai perbandingan antara probabilitas sukses dan probabilitas gagal (Asra dkk, 2017). Odds ratio digunakan untuk interpretasi parameter, dan dilambangkan dengan OR. Persamaan odds yang terbentuk pada saat $x=1$ adalah $\frac{\pi(1)}{1-\pi(1)^{\prime}}$ sedangkan pada saat $\mathrm{x}=0$ adalah $\frac{\pi(0)}{1-\pi(0)}$. Sehingga diperoleh persamaan odds ratio adalah sebagai berikut :

$O R=\frac{\frac{\pi(1)}{1-\pi(1)}}{\frac{\pi(0)}{1-\pi(0)}}$

Pengkategorian variabel bebas yang digunakan dalam penelitian ini adalah sebagai berikut:

Tabel 1. Pengkategorian variabel bebas 


\begin{tabular}{|c|c|c|c|c|}
\hline No. & Nama Variabel Bebas & $\begin{array}{c}\text { Kode } \\
\text { Variabel }\end{array}$ & Kategori & Dummy \\
\hline (1) & (2) & (3) & (4) & (5) \\
\hline \multirow[t]{2}{*}{1.} & \multirow[t]{2}{*}{ Pendidikan KRT } & \multirow[t]{2}{*}{$X_{1}$} & $\leq \mathrm{SMP}$ & 1 \\
\hline & & & $>$ SMP & 0 \\
\hline \multirow[t]{3}{*}{2.} & \multirow[t]{3}{*}{ Status pekerjaan KRT } & $X_{22}$ & Tidak bekerja & 10 \\
\hline & & \multirow[t]{2}{*}{$X_{21}$} & Non pertanian & 01 \\
\hline & & & Pertanian & 00 \\
\hline \multirow[t]{2}{*}{3.} & \multirow[t]{2}{*}{ Daerah tempat tinggal } & \multirow[t]{2}{*}{$X_{3}$} & Perdesaan & 1 \\
\hline & & & Perkotaan & 0 \\
\hline 4. & Jumlah ART & $X_{4}$ & & \\
\hline 5. & Usia KRT & $X_{5}$ & & \\
\hline \multirow[t]{2}{*}{6.} & \multirow[t]{2}{*}{ Status perkawinan KRT } & \multirow[t]{2}{*}{$X_{6}$} & Tidak/Belum kawin/ Cerai & 1 \\
\hline & & & Kawin & 0 \\
\hline
\end{tabular}

Dengan model yang diajukan adalah sebagai berikut:

$\operatorname{logit}(\pi(\boldsymbol{x}))=\ln \left(\frac{\pi(\boldsymbol{x})}{1-\pi(\boldsymbol{x})}\right)=\beta_{0}+\beta_{1} X_{1}+\beta_{21} X_{21}+\beta_{22} X_{22}+\beta_{3} X_{3}+\beta_{4} X_{4}+\beta_{5} X_{5}+\beta_{6} X_{6}$.

\section{HASIL DAN PEMBAHASAN}

\section{Gambaran Umum Status Kemiskinan Anak pada Rumah Tangga KRT Perempuan di Provinsi Bengkulu 2018}

Pengukuran status kemiskinan anak di Provinsi Bengkulu tahun 2018 pada rumah tangga KRT perempuan menunjukkan bahwa terdapat perbedaan jumlah antara anak berstatus miskin dan anak berstatus tidak miskin. Pada Gambar 2 dapat dilihat bahwa anak pada rumah tangga KRT perempuan yang berstatus miskin adalah sebesar 21,54 persen. Sedangkan anak dengan status tidak miskin pada rumah tangga KRT perempuan sebesar 78,46 persen, yaitu lebih dari 3,5 kali lipat dibanding anak berstatus miskin.

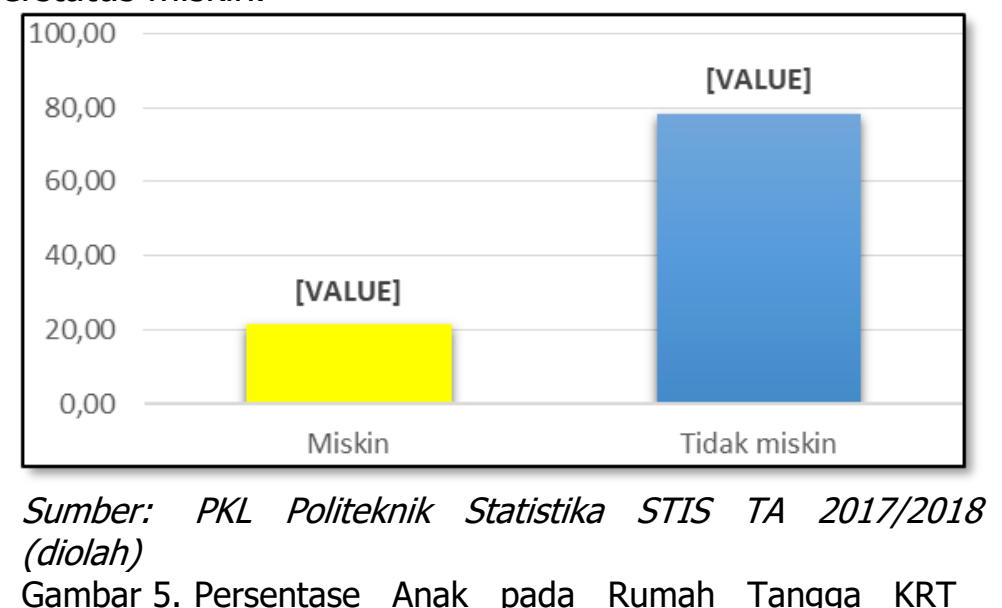
Perempuan menurut Status Kemiskinan

Adapun karakteristik kemiskinan anak pada KRT perempuan di Provinsi Bengkulu tahun 2018 antara lain sebagai berikut:

Tabel 2. Persentase anak pada rumah tangga KRT perempuan menurut status kemiskinan, pendidikan KRT, status pekerjaan KRT, daerah tempat tinggal, jumlah ART, usia KRT, dan status perkawinan KRT

Variabel

(1)
Kategori

(2)
Status kemiskinan Miskin Tidak Miskin

(3) 


\begin{tabular}{llll}
\hline \multirow{2}{*}{ Pendidikan KRT } & > SMP & 7,00 & 93,00 \\
\cline { 2 - 4 } & $\mathbf{3}$ SMP & 25,47 & 74,53 \\
\hline \multirow{3}{*}{ Status Pekerjaan KRT } & Tidak bekerja & 22,03 & 77,97 \\
\cline { 2 - 4 } & Bekerja di sektor Pertanian & 31,63 & 68,37 \\
\cline { 2 - 4 } Daerah Tempat Tinggal & Bekerja di sektor Non pertanian & 12,15 & 87,85 \\
\cline { 2 - 4 } & Perkotaan & 17,27 & 82,73 \\
\cline { 2 - 4 } Jumlah ART & Perdesaan & 23,33 & 76,67 \\
\hline \multirow{2}{*}{ Usia KRT } & $1-4$ & 15,08 & 84,92 \\
\hline \multirow{2}{*}{ Status Perkawinan KRT } & $>4$ & 36,11 & 63,89 \\
\cline { 2 - 4 } & Produktif & 22,06 & 77,94 \\
\cline { 2 - 4 } & Tidak produktif & 17,31 & 82,69 \\
\cline { 2 - 4 } & Kawin & 19,68 & 80,32 \\
\hline \multirow{2}{*}{ Sumber: PKL Politeknik Statistika STIS TA 2017/2018 (diolah) } & &
\end{tabular}

Sumber: PKL Politeknik Statistika STIS TA 2017/2018 (diolah)

Dari tabel di atas (Tabel 2) dapat diketahui bahwa anak pada rumah tangga KRT perempuan yang tergolong miskin paling banyak terdapat pada rumah tangga dengan pendidikan KRT adalah SMP ke bawah, KRT bekerja di sektor pertanian, berdomisili di daerah perdesaan, jumlah ART lebih dari 4 orang, usia KRT berkisar antara 15 hingga 64 tahun, dan berstatus kawin.

\section{Faktor-faktor yang Mempengaruhi Status Kemiskinan Anak pada Rumah Tangga KRT Perempuan di Provinsi Bengkulu 2018} berikut:

Sehingga berdasarkan hasil pengujian, model regresi logistik yang terbentuk adalah sebagai

$$
\begin{aligned}
\ln \left(\frac{\pi(\boldsymbol{x})}{1-\pi(\boldsymbol{x})}\right)= & -2,834^{*}+1,259 X_{1}{ }^{*}-1,338 X_{21}{ }^{*}-0,251 X_{22}-0,309 X_{3}+0,330 X_{4}{ }^{*}+0,008 X_{5} \\
& -0,654 X_{6}{ }^{*}
\end{aligned}
$$

Keterangan :

$*$ = signifikan pada $\mathrm{a}=5 \%$

\section{Uji Simultan}

\begin{tabular}{|c|c|c|c|}
\hline & Chi-square & $\mathrm{df}$ & Sig. \\
\hline (1) & (2) & (3) & (4) \\
\hline el Mod & 63,584 & 7 & 0,00 \\
\hline
\end{tabular}

Tabel 3. Omnibus test of model coefficients

Berdasarkan output uji likelihood ratio pada tabel di atas, diperoleh nilai statistik uji G yaitu sebesar 63,584 dengan p-value 0,000 yang lebih kecil dari tingkat signifikansi 0,05. Sehingga dengan tingkat signifikansi 5 persen terdapat cukup bukti untuk menolak $\mathrm{H}_{0}$. Hal tersebut berarti bahwa minimal terdapat satu variabel bebas ke-j yang berpengaruh terhadap status kemiskinan anak pada rumah tangga dengan kepala rumah tangga perempuan di Provinsi Bengkulu tahun 2018.

\section{Uji Parsial}

Tabel 4. Statistik uji wald, derajat bebas, dan signifikansi variabel

\begin{tabular}{lccccc}
\hline \multicolumn{1}{c}{ Nama Variabel } & Kode Variabel & Wald & Df & p-value \\
\hline \multicolumn{1}{c}{$(1)$} & $(2)$ & $(3)$ & $(4)$ & $(5)$ \\
\hline Konstanta & & Constanta & 15,828 & 1 & 0,000 \\
\hline Pendidikan KRT & $\mathrm{X}_{1}$ & 8,344 & 1 & 0,004 \\
\hline $\begin{array}{l}\text { Status Pekerjaan } \\
\text { Bekerja } \text { Ki Sektor }\end{array}$ & $\mathrm{X}_{21}$ & 17,819 & 1 & 0,000 \\
\hline
\end{tabular}




\begin{tabular}{|c|c|c|c|c|}
\hline Pertanian & & & & \\
\hline $\begin{array}{lcc}\text { Status } & \text { Pekerjaan } & \text { KRT } \\
\text { Bekerja Tidak Bekerja } & \end{array}$ & $X_{22}$ & 0,362 & 1 & 0,548 \\
\hline Daerah Tempat Tinggal & $X_{3}$ & 0,848 & 1 & 0,357 \\
\hline Jumlah ART & $\mathrm{X}_{4}$ & 19,502 & 1 & 0,000 \\
\hline Usia KRT & $X_{5}$ & 0,741 & 1 & 0,389 \\
\hline Status Perkawinan KRT & $X_{6}$ & 5,634 & 1 & 0,023 \\
\hline
\end{tabular}

Hasil statistik uji Wald (Tabel 4) digunakan untuk melihat pengaruh masing-masing variabel bebas. Variabel bebas dikatakan mempunyai pengaruh signifikan secara parsial terhadap status kemiskinan anak pada rumah tangga dengan kepala rumah tangga perempuan di Provinsi Bengkulu tahun 2018 apabila memiliki nilai statistik uji Wald lebih besar dari $\chi_{(0,05 ; 1)}^{2}$ yaitu 3,84. Selain itu untuk mengetahui apakah suatu variabel bebas memiliki pengaruh yang signifikan atau tidak dapat dilihat dari nilai $p$-value. Apabila p-value lebih kecil dari 0,05 maka dapat dikatakan bahwa variabel tersebut secara parsial memiliki pengaruh terhadap status kemiskinan anak pada rumah tangga dengan kepala rumah tangga perempuan di Provinsi Bengkulu tahun 2018. Berdasarkan tabel di atas, diketahui bahwa variabel pendidikan KRT, status pekerjaan KRT di sektor non pertanian, jumlah ART, dan status perkawinan KRT memiliki pengaruh signifikan terhadap status kemiskinan anak.

\section{Uji Kesesuaian Model (Goodness of Fit)}

Tabel 5. Hosmer and Lemeshow test

\begin{tabular}{ccc}
\hline Chi-Square & Df & Sig. \\
\hline$(1)$ & $(2)$ & $(3)$ \\
\hline 9,466 & 8 & 0,304 \\
\hline
\end{tabular}

Nilai p-value dari Hosmer and Lemeshow Test adalah sebesar 0,304 sehingga dengan tingkat signifikansi sebesar 5 persen, tidak terdapat cukup bukti untuk menolak $\mathrm{H}_{0}$, sehingga dapat dikatakan bahwa model yang digunakan telah cocok untuk menjelaskan status kemiskinan anak pada rumah tangga dengan kepala rumah tangga perempuan di Provinsi Bengkulu tahun 2018.

\section{Classification Table}

Tabel 6. Classification table

\begin{tabular}{|c|c|c|c|c|}
\hline \multicolumn{2}{|l|}{ 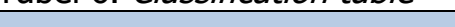 } & \multicolumn{3}{|c|}{ Predicted } \\
\hline \multirow[b]{2}{*}{ Observed } & & \multicolumn{2}{|c|}{ Miskin } & \multirow{2}{*}{$\begin{array}{c}\text { Percentage } \\
\text { Correct }\end{array}$} \\
\hline & & Tidak Miskin & Miskin & \\
\hline \multirow[t]{2}{*}{ Miskin } & Tidak Miskin & 364 & 4 & 98,9 \\
\hline & Miskin & 83 & 18 & 17,8 \\
\hline \multicolumn{2}{|c|}{ Overall Percentage } & & & 81,4 \\
\hline
\end{tabular}

Hasil perhitungan menunjukkan bahwa nilai overall percentage (Tabel 6) adalah sebesar 81,4 persen. Hal tersebut berarti bahwa model yang terbentuk dapat memprediksi dengan benar 81,4 persen status kemiskinan anak pada rumah tangga dengan kepala rumah tangga perempuan di Provinsi Bengkulu tahun 2018.

\section{Kecenderungan Status Kemiskinan Anak pada Rumah Tangga dengan KRT Perempuan Berdasarkan Variabel-variabel yang Mempengaruhinya}

Tabel 7. Estimasi koefisien regresi

\begin{tabular}{cccc}
\hline Nama Variabel Bebas & Kode Variabel & $\hat{\beta}$ & $\begin{array}{c}\text { Exp } \\
(\hat{\beta})\end{array}$ \\
\hline$(1)$ & $(2)$ & $(3)$ & $(4)$ \\
\hline Pendidikan KRT & $X_{1}$ & 0,004 & 3,5 \\
\hline Status pekerjaan KRT & $X_{21}$ & 0,000 & 0,2 \\
\hline
\end{tabular}




\begin{tabular}{|c|c|c|c|}
\hline & & \multicolumn{2}{|c|}{62} \\
\hline & $X_{22}$ & 0,548 & 0,7 \\
\hline Daerah tempat tinggal & $X_{3}$ & 0,357 & 0,7 \\
\hline Jumlah ART & $X_{4}$ & 0,000 & 1,3 \\
\hline Usia KRT & $X_{5}$ & 0,389 & 1,0 \\
\hline Status perkawinan KRT & $X_{6}$ & 0,023 & 0,5 \\
\hline
\end{tabular}

Berikut adalah kecenderungan masing-masing variabel bebas yang mempengaruhi status kemiskinan anak pada rumah tangga dengan kepala rumah tangga perempuan di Provinsi Bengkulu tahun 2018:

1. Pendidikan KRT

Pada tabel di atas dapat dilihat bahwa nilai odds ratio variabel pendidikan KRT adalah 3,520. Artinya, anak yang tinggal pada rumah tangga dengan kepala rumah tangga perempuan berpendidikan SMP ke bawah memiliki kecenderungan untuk mengalami kemiskinan 3,520 kali dibandingkan dengan kepala rumah tangga perempuan dengan pendidikan di atas SMP, dengan asumsi variabel lain konstan.

Mendukung hasil penelitian tersebut, pada penelitian yang dilakukan Bachtiar dkk (2016), Satrio (2018), Miftahuddin (2011), Putri dkk (2019), Astuti (2018), Wulandari, dkk (2016) diperoleh hasil bahwa semakin tinggi tingkat pendidikan KRT maka kecenderungan rumah tangganya mengalami kemiskinan akan berkurang. Karena dengan adanya pendidikan maka akan meningkatkan kualitas masyarakat dan dengan tingginya pendidikan maka masyarakat dapat memilih jenis pekerjaan dalam meningkatkan kesejahteraan keluarganya (Putri, dkk 2019).

\section{Status Pekerjaan KRT}

Nilai odds ratio untuk variabel status pekerjaan KRT di sektro non pertanian adalah sebesar 0,262 . Berarti anak yang tinggal pada rumah tangga dengan kepala rumah tangga perempuan yang bekerja di sektor non pertanian memiliki kecenderungan mengalami kemiskinan sebesar 0,262 dibandingkan kepala rumah tangga yang bekerja di sektor pertanian. Atau dapat dikatakan bahwa anak pada rumah tangga KRT perempuan yang bekerja di sektor pertanian cenderung mengalami kemiskinan lebih besar $(1 / 0,262=3,817$ kali) dibandingkan KRT perempuaan yang bekerja di sektor non pertanian, dengan asumsi variabel lain konstan. Hasil tersebut sejalan dengan penelitian yang dilakukan oleh Wulandari, dkk (2016), Astuti (2018), Miftahuddin (2011), dan Satrio (2018). Sejalan dengan hal tersebut Miftahuddin (2011) dan Satrio (2018) diperoleh hasil bahwa KRT yang bekerja pada sektor pertanian memiliki kecenderungan lebih tinggi untuk mengalami kemiskinan dibandingkan jika bekerja di sektor non pertanian.

\section{Jumlah ART}

Nilai odds ratio yang diperoleh sebesar 1,391. Sehingga setiap penambahan satu anggota rumah tangga maka kecenderungan anak pada rumah tangga tersebut untuk mengalami kemiskinan meningkat sebesar 1,391, dengan asumsi variabel lain konstan. Penelitian yang dilakukan oleh Miftahuddin (2011), Astuti (2018), Putri dkk (2019), Wulandari, dkk (2016) bahwa kecenderungan rumah tangga dengan ART banyak akan lebih tinggi untuk mengalami kemiskinan dibandingkan rumah tangga dengan ART sedikit.

\section{Status Perkawinan KRT}

Nilai odds ratio untuk variabel status perkawinan pada tabel di atas diketahui sebesar 0,520. Hal tersebut berarti anak yang tinggal pada rumah tangga dengan kepala rumah tangga perempuan berstatus tidak/belum kawin/cerai memiliki kecenderungan untuk miskin sebesar 0,520 dibandingkan dengan kepala rumah tangga berstatus kawin. Atau dapat dikatakan bahwa anak pada rumah tangga KRT perempuan berstatus kawin memiliki kecenderungan untuk miskin lebih 
besar $(1 / 0,520=1,923$ kali) jika dibandingkan dengan KRT perempuan berstatus tidak/belum kawin/cerai, dengan asumsi variabel lain konstan. Hasil tersebut tidak sejalan dengan penelitian yang dilakukan Sari (2018), dan Junaida (2019) bahwa pada rumah tangga yang memiliki KRT berstatus cerai maka akan meningkatkan kecenderungan rumah tangga tersebut untuk mengalami kemiskinan.

\section{KESIMPULAN}

Berdasarkan hasil permbahasan di atas, dapat ditarik kesimpulan bahwa masih terdapat cukup banyak anak pada rumah tangga KRT perempuan di Provinsi Bengkulu 2018 yang tergolong miskin, yaitu sebanyak 21,54 persen. Dengan anak yang berstatus miskin paling banyak ditemukan pada rumah tangga dengan karakteristik pendidikan KRT rendah ( $\leq$ SMP), KRT bekerja di sektor pertanian, tinggal di daerah perdesaan, memiliki jumlah ART lebih dari 4 orang, KRT berusia produktif, dan KRT berstatus kawin. Adapun variabel-variabel yang berpengaruh terhadap status kemiskinan anak tersebut adalah pendidikan KRT, status pekerjaan KRT, jumlah ART, serta status perkawinan KRT. Serta kecenderungan seorang anak untuk mengalami kemiskinan lebih besar ditemukan pada rumah tangga dengan pendidikan KRT SMP ke bawah, KRT bekerja di sektor pertanian, jumlah ART banyak, dan KRT berstatus kawin.

Adapun saran yang dapat diberikan adalah bagi pemerintah daerah hendaknya melakukan pemberdayaan terhadap KRT perempuan dengan menyediakan lapangan pekerjaan sesuai dengan latar belakang yang dimiliki, juga melakukan pelatihan untuk meningkatkan keterampilan. Selain itu juga bagi pemerintah daerah diharapkan lebih memperhatikan masalah pendidikan untuk meningkatkan kualitas sumber daya manusia, dan juga lebih menggiatkan sosialisasi pentingnya penggunaan alat kontrasepsi untuk menekan angka kelahiran sehingga dapat mengurangi peningkatan jumlah anggota rumah tangga. Sedangkan untuk peneliti selanjutnya sebaiknya mengkaji lebih jauh variabel-variabel bebas lainnya yang diduga berpengaruh terhadap kemiskinan anak dengan melibatkan karakteristik anak itu sendiri.

\section{DAFTAR PUSTAKA}

Ahmad, N. R., Kanto, S., \& Susilo, E. (2015). Fenomena Kemiskinan Dari Perspektif Kepala Rumah Tangga Perempuan Miskin (Studi Fenomenologi Tentang Makna dan Penyebab, Serta Strategi Penanggulangan Feminisasi Kemiskinan di Desa Wonorejo, Kecamatan Singosari, Kabupaten Malang). Wacana, 18(4), 221-230.

Ambariyanto. (2013). Kemiskinan Multidimensi pada Anak. Jurnal Media Trend, 8(2), 118-127.

Asra, A., dkk. (2017). Analisis Multivariabel: Suatu Pengantar. Bogor: IN MEDIA.

Astuti, E. W. (2018). Analisis Faktor-Faktor yang Mempengaruhi Kemiskinan Rumah Tangga (Kasus di Kabupaten Semarang). Economics Development Analysis Journal, 7 (2), 162-185.

Bachtiar, N., Rasbi, M. J., \& Fahmi, R. (2016). ANALISIS KEMISKINAN ANAK BALITA PADA RUMAH TANGGA DI PROVINSI SUMATERA BARAT. Jurnal Kependudukan Indonesia, 11(1), 29-38.

Badan Pusat Statistik [BPS]. (2008). Kemiskinan dan Ketimpangan. Diakses tanggal 19 Oktober 2019 melalui https://www.bps.go.id/subject/23/kemiskinan-dan-ketimpangan.html.

Badan Pusat Statistik [BPS]. (2018). Profil Kemiskinan di Indonesia September 2017. Jakarta: BPS.

Badan Pusat Statistik [BPS] \& UNICEF. (2017). Analisis Kemiskinan Anak dan Deprivasi Hak-hak Dasar Anak di Indonesia. Jakarta : Badan Pusat Statistik.

Miftahuddin. (2011). Analisa Karakteristik Rumah Tangga Miskin dengan Metode Regresi Logistik Terbaik. Jurnal Matematika, Statistika, dan Komputasi, 7(2), 79-91.

Probosiwi, Ratih. (2015). PEREMPUAN DAN PERANNYA DALAM PEMBANGUNAN KESEJAHTERAAN SOSIAL. Jurnal Kajian IImu Administrasi Negara, 3(1), 41-56.

Putri, R. Y., Azhar, Z., \& Putri, D. Z. (2019). ANALISIS KEMISKINAN BERDASARKAN GENDER DI PROVINSI SUMATERA BARAT. Jurnal Kajian Ekonomi dan Pembangunan, 1(2), 603-612.

RI (Republik Indonesia). (2014). UU Republik Indonesia nomor 35 tahun 2014 tentang Perubahan atas UU nomor 23 tahun 2002 Perlindungan Anak. Penjelasan Dalam Tambahan Lembaran Negara Republik Indonesia, No. 5606. Sekretariat Negara, Jakarta.

Sari, E. N. (2018). Pengaruh Status Perkawinan Dan Kondisi Ekonomi Rumah Tangga Terhadap Kemiskinan Anak Di Provinsi Banten Tahun 2017. Jurnal Penelitian Kesejahteraan Sosial, 17(4), 365-374.

Satrio, I. (2018). Sektor Pertanian: Faktor Utama Penentu Kemiskinan Jawa Barat, Jurnal Sosial Ekonomi dan Kebijakan Pertanian. Agriekonomika, 7(2), 188-196.

Sekarwati, A., Nurfadilla, H., \& Salamor, R. E. (2019). Kemiskinan Multidimensi dan Variabel-variabel yang 
Mempengaruhinya di Provinsi Bengkulu Tahun 2017. [Skripsi]. Jakarta: Politeknik Statistika STIS.

Wulandari, N. R., Harafah, H. LM., \& Saenong, Z. (2016). FAKTOR-FAKTOR YANG MEMPENGARUHI KEMISKINAN RUMAH TANGGA DI KOTA KENDARI TAHUN 2014. Jurnal Progres Ekonomi Pembangunan, $1(1), 111-119$ 